\title{
PENGUKUHAN KUASA PEMERINTAHAN KESULTANAN MELAYU KEDAH DALAM UNDANG-UNDANG KEDAH
}

\author{
Strengthening The Powers of Malay Sultanate of Kedah in Undang-Undang Kedah
}

\author{
Nor Afiza Mohd Nasir \\ norafizanasir@yahoo.com \\ Salmah Jan Noor Muhammad \\ salmahjan@upm.edu.my
}

Universiti Putra Malaysia

\begin{abstract}
ABSTRAK
Pada zaman pemerintahan kesultanan Melayu, Undang-Undang Kedah merupakan salah satu naskhah utama dalam sejarah penulisan undang-undang adat dan terpenting dalam menonjolkan kekuasaan golongan raja dalam mentadbir sesebuah negara selain membicarakan pelbagai aspek kehidupan masyarakat Melayu Kedah. Oleh itu, objektif kajian ini ialah mengenal pasti kaedah pengukuhan kuasa yang diwujudkan oleh raja di samping menghuraikan implikasi yang wujud hasil pengukuhan kuasa tersebut terhadap pemerintahan kesultanan Melayu Kedah. Hasil kajian menunjukkan pengukuhan kuasa pemerintahan kesultanan Kedah wujud melalui pelbagai kaedah iaitu pembatasan hubungan raja dengan rakyat, kawalan sosial dan pembentukan sifat kepatuhan rakyat kepada golongan raja. Sehubungan itu, perbincangan ini berlandaskan Teori Kuasa yang diperkenalkan oleh John R.P. French dan Bertram Raven (1959) di samping menggunakaan kaedah kepustakaan dan analisis kandungan.
\end{abstract}

Kata kunci: kuasa; raja; rakyat; kesultanan Melayu Kedah; Undang-Undang Kedah

\begin{abstract}
During the Malay Sultanate era, Undang-Undang Kedah is one of the manuscripts that is important in highlighting the power of the king in administering a country and discussing various aspects of community life. Thus, this study will identify methods to strengthening the powers established by the king as well as describe the implications of strengthening the powers against the Malay sultanate of Kedah. Findings show that the strengthening of powers of the sultanate of Kedah is created through various methods such as limitations in relationship between the king and the folks, social control and through formation obedience offolks to the king. Therefore, discussion is based on the Power Theory introduced by John R.P. French and Bertram Raven (1959), library methods and content analysis.
\end{abstract}

Keywords: power; king; folks; Malay Sultanate of Kedah; Undang-Undang Kedah.

\section{PENGENALAN}

Pada zaman kesultanan Melayu, pemerintahan atau politik merupakan aspek penting dalam mencorak dan mengatur kehidupan sesebuah masyarakat. Persoalan berkaitan politik pemerintahan kesultanan Melayu sentiasa mendapat perhatian sarjana di mana perbincangan dan penilaian dilihat dari pelbagai sudut pandangan (Jelani Harun, 2016). Ini kerana pemerintahan beraja merupakan salah satu ciri utama dalam mewarnai sistem politik Melayu tradisional. Menurut Muhammad Mustaqim Mohd Zaif (2016), raja bukan sahaja berperanan sebagai pemerintah agung yang sah dalam aspek militer dan pentadbiran, bahkan merangkumi segala yang berkaitan dengan agama, budaya, adat dan istiadat 
masyarakat. Hal ini diperkukuhkan dengan pendapat Noriah Taslim (2008) yang juga meletakkan raja sebagai kuasa tertinggi dalam tampuk pemerintahan. Menurut beliau, raja-raja Melayu terjelma melalui konsep mitos yang menjelmakan mereka sebagai individu yang supra-manusia, iaitu mempunyai keupayaan luar biasa yang dahsyat, mengagumkan dan menggerunkan. Kehadiran raja juga bukan sahaja mampu mentransformasikan alam malah menjadikan lebih gemilang dan mewah. Secara keseluruhannya, unsur mitos inilah yang menonjolkan peribadi raja bukan sahaja perkasa dan berdaulat malah kebal.

Zaman kesultanan Melayu telah memperlihatkan sistem politik Melayu adalah berasaskan sistem politik Melayu tradisional yang terbahagi kepada dua kelompok iaitu golongan pemerintah yang terdiri daripada raja dan pembesar dan golongan diperintah terdiri daripada rakyat dan hamba. Dalam hal ini, golongan pemerintah terutamanya raja mempunyai kuasa mutlak ke atas sistem politik, ekonomi dan sosial masyarakat. Di sini jelas menampakkan bahawa kekuasaan raja amat diperlukan bagi mengawal rakyat dalam segenap aspek kehidupan. Di samping itu, raja-raja Melayu juga telah dikaitkan dengan konsep daulat atau tulah di mana raja dipercayai mempunyai kuasa ghaib dalam bertindak ke atas diri manusia yang berada di bawah kekuasaannya. Konsep tulah dan daulat telah menjadi salah satu cara yang digunakan oleh golongan raja dalam memperkukuhkan kedudukan mereka sebagai kuasa tertinggi dalam pentadbiran sesebuah negeri atau negara. Ini sekaligus memperlihatkan raja mempunyai hak terhadap rakyat jelata dan negara yang ditadbir oleh baginda. Pada zaman ini juga, hak raja tidak boleh dipersoalkan. Hal ini kerana rakyat yang ingkar pada zaman tersebut akan dianggap derhaka. Menurut Siti Hawa Haji Salleh (2006) rakyat yang patuh dan taat akan menerima ganjarannya sementara yang menentang akan menerima padahnya. Justeru, sebagai kuasa tertinggi raja selalunya digambarkan dengan pelbagai sifat yang unggul dan hebat iaitu digambarkan dengan kedaulatan, kuasa luar biasa dan sebagainya. Sifat-sifat yang dimiliki golongan inilah yang mencorakkan sistem pemerintahan pada zaman kesultanan Melayu yang mempunyai susun lapis yang berteraskan sistem feudal. Contohnya, bagi membuktikan kesahihan konsep tulah ini, maka pada zaman kesultanan Melayu telah dinyatakan beberapa peristiwa yang dianggap benarbenar wujud bagi menggambarkan kekuasaan raja. Misalnya, melalui peristiwa Sang Rajuna Tapa yang telah menderhaka kepada raja.

"Dengan takdir Allah Taala, maka rumah Sang Rajuna Tapa itu pun roboh, dan kerengkiangnya pun tumbang dan beras pun habis menjadi tanah, dan Sang Rajuna Tapa laki-isteri pun habis menjadi batu".

(Sejarah Melayu: 53)

Peristiwa di atas jelas menampakkan bahawa konsep tulah telah mengawal masyarakat daripada menderhaka kepada Raja. Disebabkan oleh kekuasaan yang dimiliki inilah yang akan mewujudkan ketaatan dalam diri masyarakat terhadap pemerintah. Ini kerana dengan kuasa yang dimiliki raja akan mewujudkan satu pemikiran rakyat terhadap raja iaitu raja merupakan individu yang mempunyai perhubungan ghaib antara peribadi raja dan kuasa kosmos (Noriah Taslim, 2008). Menerusi peristiwa dalam petikan di atas, memperlihatkan rakyat tidak akan menderhaka kerana takut nasib yang akan menimpa diri disebabkan tindakan yang menderhaka kepada raja.

Terdapat beberapa pengkaji yang telah menulis tentang aspek pengukuhan kuasa mahupun berkaitan undang-undang. Antaranya, tulisan Jelani Harun (2008) berjudul Undang-Undang Kesultanan Melayu dalam Perbandingan. Dalam buku ini, isu berkaitan undang-undang telah menjadi fokus utama kajian. Salah satu topik yang menjadi perbincangan ialah membicarakan semula undang-undang zaman kesultanan Melayu iaitu yang berkaitan sejarah persuratan dan tamadun masyarakat Melayu. Penulisan kajian ini telah dilakukan dalam konteks perbandingan, sama ada dari segi sumber ataupun interprestasi, meliputi naskhah undang-undang adat dari kesultanan Melayu di Malaysia dan Indonesia. Oleh yang demikian, dalam meneliti aspek tersebut, penulisan buku ini telah melihat kepada beberapa naskhah manuskrip sebagai sumber undang-undang kesultanan Melayu yang utama. Antaranya, Undang-Undang Melaka, Undang-Undang Pahang, Undang-Undang Hamba Lari Negeri Selangor, Undang-Undang Sembilan Puluh Sembilan, Undang-Undang Kedah, Undang-Undang Laut Melaka, Undang-Undang Pelabuhan dan sebagainya. 
Selain itu, pengamatan beralih kepada makalah Jelani Harun (2008) dalam jurnal Sari jilid ke 26 yang berjudul "Kajian Naskhah Undang-Undang Adat Melayu di London". Dalam makalah ini, isu yang menjadi fokus utama pengarang ialah mengesani minat awal sarjana Inggeris terhadap penulisan undang-undang adat Melayu, fokus kedua ialah untuk mengenal pasti ciri-ciri khusus undang-undang adat Melayu selain menilai bentuk hubungan tradisi Melayu dengan pemikiran Islam terhadap konsep keadilan undang-undang bagi masyarakat Melayu masa silam. Secara keseluruhannya, dapatan tulisan ini memperlihatkan bahawa kajian terhadap undang-undang kesultanan Melayu telah menarik minat ramai pegawai Inggeris sejak abad ke-18. Penulisan ini juga memperlihatkan bagaimana naskhah-nashah undang-undang adat seperti Undang-Undang Melaka, Undang-Undang Kedah, Undang-Undang Johor dan Undang-Undang Laut Melaka yang telah diperoleh oleh sarjana Inggeris untuk dijadikan bahan kajian mereka. Selain itu, dapatan penting yang diperoleh daripada hasil kajian ini ialah Islam telah mengubah corak pemerintahan raja-raja Melayu daripada pautan kukuh kepada Hindu berubah paksi kepada asas pemerintahan dalam Islam sehingga melahirkan undang-undang Islam. Di sini jelas memperlihatkan bahawa kajian ini telah membuka ruang kepada pengkaji lain dalam memahami dengan lebih mendalam berkaitan undang-undang Adat Melayu yang pernah wujud pada zaman kesultanan Melayu.

Seterusnya, pengamatan berfokus kepada kajian yang dilakukan oleh Norhayati Ab. Rahman (2009) yang melihat kepada "Adat dan Istiadat Dalam Sastera Sejarah Sebagai Peneguhan Kepada Ketuanan dan Kekuasaan Raja Melayu". Fokus kajian ini lebih terarah kepada naskhah Sejarah Melayu. Pada bahagian awal kajian, Norhayati Ab. Rahman telah memberi pengenalan berkaitan konsep adat dan konsep adat istiadat. Seterusnya, kajian juga telah menyentuh berkaitan asal usul keturunan raja yang berasal daripada keturunan yang agung, unggul dan berkuasa. Kajian ini juga telah menerangkan mengenai wa'adat antara Seri Teri Buana/Sang Sapurba dengan Demang Lebar Daun. Peristiwa ini dimasukkan bagi memaparkan kekuasaan yang dimiliki oleh golongan pemerintah iaitu raja dalam mengekalkan kuasanya dalam sesebuah tampuk pemerintahan. Seterusnya, pada bahagian analisis kajian lebih terarah kepada adat istiadat yang terdapat dalam Sejarah Melayu iaitu yang berhubung dengan segala bentuk perayaan adat dan agama, protokol di istana, adat menjunjung duli, taraf pembesar istana, adat istiadat memberi persalinan, adat istiadat ditandu dan diusung, adat istiadat pertabalan, adat istiadat mengarak surat menaiki gajah dan lainlain. Selain itu, kajian ini juga terarah kepada adat yang berhubung dengan segala peraturan dan pantang larang istana kepada rakyat. Antaranya, larangan kekuningan, peraturan membuat rumah, peraturan membuat perahu, larangan menggunakan keris yang mempunyai sarung diperbuat daripada emas dan perak dan sebagainya. Di samping itu, kajian ini juga melihat kepada peraturan dan larangan yang dikenakan kepada rakyat melalui larangan terhadap alat-alat dan perkakas raja serta melihat kepada adat istiadat dan protokol. Antaranya, adat istiadat memberi gelar atau gelaran kepada orang besar atau rakyat, adat istiadat memberi pangkat dan jawatan tadbir, adat istidat ketika raja berangkat, adat istiadat perkahwinan diraja dan sebagainya. Kesimpulannya, kajian yang dilakukan merupakan satu cara atau langkah yang telah diambil bagi memperlihatkan aspek ketuanan dan kekuasaan raja terhadap rakyat yang diperintah. Situasi ini membuktikan raja mempunyai kuasa mutlak ke atas rakyat.

Kajian Jelani Harun (2016) yang berjudul "Pemerintahan dan Politik dalam Naskhah Melayu" juga telah diamati. Fokus utama kajian ialah berkaitan politik tradisional Melayu iaitu daripada sebelum kedatangan Barat sehinggalah kedatangan Barat yang telah memperkenalkan sistem politik pemerintahan yang baharu. Dalam hal ini, kajian telah memperlihatkan bagaimana golongan raja-raja Melayu memerintah berlandaskan moral dan akhlak iaitu melalui asuhan tradisi sehingga mampu membina pelbagai kejayaan dalam membangunkan peradaban bangsa. Ini kerana, sistem politik yang berteraskan adab keperibadian raja mampu melahirkan negara yang maju dan seimbang. Kajian juga telah memperlihatkan kedaulatan raja yang tercatat dalam naskhah-naskhah Melayu. Antara naskhah yang memperlihatkan politik kesultanan Melayu ialah melalui kewujudan naskhah ketatanegaraan Melayu seperti Taj al-Salatin, Bustan al-Salatin, Nasihat al-Muluk dan Thamarah al-Muhimmah. Manakala, naskhah yang memperlihatkan amalan politik dapat diteliti dalam naskhah-naskhah historiografi, undang-undang dan adat istiadat. Di samping itu, kajian juga telah membicarakan berkaitan usaha yang telah dijalankan oleh pengarang Melayu dalam 
memaparkan isu atau perkara yang berkaitan sejarah politik raja-raja Melayu. Secara keseluruhan, kajian ini telah memperlihatkan peri pentingnya naskhah Melayu dalam memerikan politik atau pemerintahan masyarakat Melayu suatu masa dahulu.

Berdasarkan kajian-kajian lepas, walaupun terdapat pengkaji yang mengkaji aspek pengukuhan kuasa sebagai bahan kajian, namun aspek pengukuhan kuasa dalam naskhah UndangUndang Kedah jarang dibincangkan sebagai bahan perbincangan. Kebanyakannya berfokus kepada naskhah yang bercorak sejarah dan ketatanegaraan seperti mana kajian yang dilakukan oleh Norhayati Abd.Rahman dan Jelani Harun. Jelani Harun (2008) menjelaskan penelitian manuskrip undang-undang Melayu terutama daripada kalangan sarjana Melayu agak perlahan dan kurang memberangsangkan. Menurutnya, lagi penerbitan esei atau buku yang berkaitan kajian manuskrip undang-undang Melayu juga tidak banyak. Di samping itu, bahan-bahan yang berkaitan dengan undang-undang adat Melayu hanya menjadi sumber sampingan para sarjana dalam pengajian sejarah undang-undang sejarah Islam di Malaysia. R. J. Wilkinson (1970) pula menyifatkan sastera undangundang hanyalah sebagai digest dan bukannya sebagai undang-undang (code) yang sebenar. Oleh itu, kajian ini akan menumpukan kepada kaedah pengukuhan kuasa yang diwujudkan oleh raja dan menghuraikan implikasi yang wujud hasil pengukuhan kuasa terhadap pemerintahan kesultanan Melayu Kedah.

\section{METODOLOGI}

Kajian ini akan menggunakan kaedah kepustakaan dan kaedah analisis teks dalam mengumpul data dan maklumat berkaitan aspek yang ingin dikaji. Dalam kajian ini, naskhah undang-undang adat iaitu Undang-Undang Kedah akan menjadi bahan utama. Kajian ini mempunyai beberapa tahap perancangan, antaranya ialah tahap pemilihan bahan, pengumpulan data, penganalisisan data dan seterusnya tahap membuat kesimpulan. Pada tahap pemilihan bahan, bahan dipilih berdasarkan kepada naskhah yang wujud semasa zaman kesultanan Melayu. Pada tahap ini, bahan akan diteliti sama ada sesuai dalam memberi gambaran berkaitan aspek yang ingin dianalisis. Seterusnya, setelah pemilihan bahan dilakukan data akan dikumpul berdasarkan objektif yang telah ditetapkan. Pada tahap penganalisisan data, setiap data akan dianalisis bagi menjawab persoalan kajian dan seterusnya dapatan kajian akan dilakukan bagi memperlihatkan kaedah yang diwujudkan oleh golongan pemerintah iaitu raja dalam mengukuhkan kuasa pemerintahannya.

Kajian ini menggunakan Teori Kuasa yang diketengahkan oleh John R. P. French dan Bertram Raven (1959). Menerusi teori yang dikemukakan, terdapat beberapa prinsip yang menjadi asas dalam mewujudkan sesebuah kekuasaan.

Lima prinsip asas kekuasaan yang dikemukakan ialah:
i. $\quad$ Kekuasaan Ganjaran (Reward Power)
ii. Kekuasaan Paksaan (Coercive Power)
iii. Kekuasaan Sah (Legitimate Power)
iv. Kekuasaan Rujukan (Referent Power)
v. Kekuasaan Pakar (Expert Power)

Prinsip yang akan menjadi dasar kepada analisis kajian ialah prinsip kekuasaan paksaan yang mengetengahkan beberapa ciri yang sesuai antaranya:

1. memfokuskan kepada manipulasi hukuman kepada perilaku yang melakukan sesuatu yang tidak baik atau tidak diingini dalam sesebuah organisasi.

2. mengutamakan kekuasaan ketua dalam mewujudkan rasa patuh orang bawahan melalui hukuman yang akan diberikan.

3. hukuman akan mendorong orang bawahan untuk taat kepada arahan atau perintah ketua. 
Justeru, Teori Kuasa ini sesuai untuk menganalisis data kajian kerana perkara yang akan dianalisis tertumpu kepada kuasa yang diikuti oleh hukuman kepada si pelaku kesalahan dalam sesebuah organisasi.

\section{ANALISIS DAN PERBINCANGAN}

Pada bahagian analisis ini, terdapat beberapa kaedah yang diaplikasi oleh golongan pemerintah iaitu raja dalam mengukuhkan kuasa mereka semasa zaman kesultanan Melayu Kedah. Kaedah tersebut ialah melalui:

i. pembatasan hubungan raja dengan rakyat (Hukum Berbahasa)

ii. mewujudkan kawalan sosial (Adat Istiadat dan Pantang Larang)

iii. pembentukan sifat kepatuhan rakyat kepada golongan raja (Undang-Undang Jenayah)

\section{PEMBATASAN HUBUNGAN RAJA DENGAN RAKYAT}

Pada zaman kesultanan Melayu, hubungan raja dan rakyat sebenarnya ditentukan berdasarkan keagungan dan kebesaran yang dimiliki oleh golongan pemerintah itu sendiri. Menurut Zainal Abidin Borhan (2016) keagungan dan kemuliaan raja sebenarnya diperoleh melalui kuasa. Kuasa sebenarnya mampu membentuk sebuah negara yang memiliki masyarakat yang tenteram dan makmur (Zubir Idris, 2009) Namun, keagungan dan kemuliaan seorang raja dan keturunannya sebenarnya terletak pada sejauh mana hubungan mereka dengan pembesar dan golongan rakyat. Pada zaman pemerintahan kesultanan Melayu khususnya, hubungan raja dan rakyat dapat dilihat melalui sumpah setia atau kontrak sosial yang dipanggil waad seperti mana yang yang terdapat dalam naskhah Sulalatus Salatin. Dalam konteks ini, waad merupakan perjanjian yang menjadi simbol kepada permulaan hubungan raja dan rakyat. Oleh yang demikian, bagi memperlihatkan batasan hubungan raja dan rakyat, beberapa kaedah telah diwujudkan dalam naskhah Undang-Undang Kedah. Kaedah ini diwujudkan oleh golongan raja dengan tujuan utama untuk memperkukuhkan kuasa mereka. Perbatasan perhubungan raja dan rakyat dapat dilihat melalui hukum berbahasa. Secara umumnya, bahasa merupakan alat komunikasi yang digunakan oleh golongan raja bagi berhubung dengan rakyat dibawah pemerintahanya.

Dalam naskhah Undang-Undang Kedah, hukum berbahasa merupakan salah satu cara raja memperkukuhkan kekuasaan baginda. Menurut Harun Mat Piah et al. (2000), bahasa merupakan salah satu keistimewaan yang diberikan kepada raja. Menurut beliau, keistimewaan yang dimiliki oleh raja tidak boleh digunakan oleh rakyat. Hal ini demikian, kerana perkara ini telah menjadi larangan diraja kepada kelompok masyarakat. Hukum berbahasa dalam Undang-Undang Kedah telah diperlihatkan pada bahagian IV teks ini iaitu Cara Membuat Bunga Emas. Ini dijelaskan seperti petikan di bawah:

"Bermula hukum bahasa raja-raja itu lima perkara. Pertama, titah; kedua, kami; ketiga, kita; keempat, berpatik; kelima, derma kurnia. Maka tiada siapa-siapa berkata yang demikian itu. Barang siapa yang mengatakan kata ini, hukumnya jika hamba raja, dibunuh, jika orang keluaran, digocoh mulutnya, jangan jadi teladan pada yang lain, tulah papa kerana raja itu pun ganti Allah taala di dalam dunia ini tak dapat tiada dapatlah melakukan barang kehendaknya."

(Undang-Undang Kedah, 2005:26)

Hukum berbahasa ini juga telah diulang pada bahagian V (Undang-undang Hijrah Seribu Seratus Sembilan Puluh Sembilan) iaitu seperti petikan di bawah:

"Fasal pada menyatakan hukum bahasa raja-raja itu lima perkara. Pertama, titah; dan kedua, kami; dan ketiga kita; dan keempat, berpatik; dan kelima, derma kurnia. Maka 
kelima perkara ini tiada boleh berkata-kata dengannya mereka yang keluaran. Barang siapa melalui akan dia, hukumnya dibunuh, jika ia hamba raja, dan digocoh mulutnya jika ia (orang) keluaran supaya jangan menjadi tauladan kepada mereka yang lain kerana mempesakai papa kepada raja itu ganti Allah taala di dunia ini”.

(Undang-Undang Kedah, 2005:40)

Berdasarkan petikan di atas, pengukuhan kuasa raja telah diperlihatkan melalui hukum berbahasa iaitu rakyat dilarang daripada menggunakan perkataan seperti titah, kami, kita, berpatik dan derma kurnia. Berdasarkan petikan tersebut, hukum berbahasa ini penting kerana ia telah menjadi salah satu peraturan yang harus dipatuhi oleh rakyat. Petikan di atas juga jelas memperkatakan jika rakyat melanggar peraturan ini maka mereka akan menerima hukuman berat iaitu dibunuh bagi hamba raja dan digocoh mulutnya jika mereka daripada orang keluaran. Ini menunjukkan bahawa golongan raja merupakan individu yang istimewa.

\section{MEWUJUDKAN KAWALAN SOSIAL}

Pada zaman kesultanan Melayu, golongan raja telah mewujudkan pengawalan sosial kepada rakyat terutamanya dalam hal yang berkaitan adat istiadat dan larangan istana. Melalui pengawalan ini, kuasa raja dapat dikukuhkan sebagai kuasa tertinggi dalam sesebuah pemerintahan. Jika dilihat dalam naskhah Undang-Undang Kedah, hal yang berkaitan adat istiadat dan larangan ini diwujudkan khas bagi golongan raja sahaja. Menurut Yusof Iskandar (1977), perkara ini diwujudkan adalah tidak lain daripada percubaan mencipta suatu "hukum" dan tatacara negeri supaya pemerintah dapat dibezakan daripada golongan yang diperintah. Larangan inilah yang menonjolkan keistimewaan golongan raja. Ini diperkukuhkan lagi dengan kenyataan Harun Mat Piah et al. (2000) yang menjelaskan keistimewaan ini penting ditekankan kerana perkara ini mampu membezakan golongan raja dengan golongan pembesar dan rakyat biasa. Antara larangan yang dijadikan hukum atau undang-undang yang terdapat dalam Undang-Undang Kedah ialah berkaitan larangan kekuningan, adat berpakaian (memakai kain nipis), dan adat menyambut atau menerima surat utusan. Menurut Norhayati Ab.Rahman (2009), larangan kekuningan merupakan larangan yang telah ditetapkan oleh raja. Dalam larangan itu, semua yang berwarna kuning adalah menjadi hak eksekutif raja dan rakyat biasa dilarang menggunakannya. Larangan ini dapat dilihat dalam petikan di bawah:

\footnotetext{
"Pakaian raja-raja empat perkara. Pertama, berkain kuning; kedua, bertilam pandak empat bersegi, peterana, namanya; dan ketiga, payung ubur-ubur dan keempat, tombak cabang. Maka tiadalah dapat siapa-siapa memakai dia. Hukumnya rampas. Dan, lima perkara yang dapat diperbuat orang keluaran diampuni maafkan oleh raja; pertama kepada mempelai berarak boleh pakai kekuningan dan beremas dan berpayung besar dipegang orang dan bersorak-sorak, dinamakan raja sehari”.
}

(Undang-Undang Kedah, 2005:26)

Berdasarkan petikan di atas, warna kuning hanya boleh digunakan oeh golongan raja sahaja. Dalam naskhah ini, pengecualian hanya diberikan kepada mempelai. Selain larangan memakai pakaian warna kuning, penggunaan warna kuning juga terhad kepada barangan lain seperti tilam, bantal sapu tangan dan sebagainya. Peraturan ini dapat dilihat dalam petikan di bawah:

"Demikian lagi bertilam beralas kuning, batang bantal kuning atau sapu tangan kuning, maka ia itu hukumnya dicarikkan oleh segala yang melihat itu, suatu pun tiadalah perkataan lagi”. 
Kekuasaan raja terhadap rakyat juga dapat dilihat dari segi adat berpakaian. Dalam hal ini, rakyat dilarang daripada memakai pakaian yang nipis, jarang dan berbayang-bayang. Jika rakyat ingkar, hukuman berat akan dikenakan iaitu hukuman bunuh. Ini dapat dilihat dalam petikan di bawah:

\begin{abstract}
"Maka ketahui olehmu bahawa tiada harus dipakai sekalian/pada orang besar-besar itu. Jikalau pakai oleh orang lain dengan tiada ada nama anugerah itu dibunuh hukumannya itu. Demikian lagi tiada dapat memakai kain yang nipis, jarang, berbayang-bayang itu seperti khasa dan halimunan pada balai raja atau di dalam kerja melaikan dengan titah kurnia atau ada dilorekkan boleh pakaiannya. Jikalau lain daripada itu, nescaya dicarikkan atau ditolakkan hukumnya".
\end{abstract}

(Undang-Undang Kedah, 2005:49)

Pengawalan sosial juga dapat dilihat melalui adat menyambut atau menerima surat utusan. Menurut Norhayati Ab. Rahman (2009), surat utusan daripada kerajaan lain disambut dengan adat istiadat bagi melambangkan kekuasaan dan kebesaran raja yang memerintah. Selain itu, sambutan ini bagi memaparkan ketinggian seni dan adat istiadat masyarakat Melayu. Contohnya:

\begin{abstract}
"Maka adat menyambut surat lompeni itu bergajah, payung cina, tunggul dua belas, arakarakan dengan gendang dan serunai, tempat surat itu seroja. Tatkala sampai ke balai, dipasang bedil kurnia lima kurnia lima kali. Jika surat saudagar besar pun demikian juga adatnya; dan gurnador Melaka pun seperti ini juga adatnya menyambut surat raja, sama raja-raja menyambut dia kerana kafir yang jenis tersebut itu, terlebih mulianya pada bedil. Maka sebab pun demikian, perintah dan adat menyambut surat utusan daripada Raja Pattani tunggul enam belas, payung ubur-ubur putih dua, berjorong, bertetapan, gong, gendang, serunai, nafiri”.
\end{abstract}

(Undang-Undang Kedah, 2005:49)

Dalam Undang-Undang Kedah, setiap surat utusan kerajaan disambut dengan cara yang berbeza. Contohnya, surat dari Jambi Sumatera disambut dengan alat-alat kebesaran seperti tunggul dua belas, payung ubur-ubur putih satu, lapiknya seroja, gong, gendang, serunai. Manakala, surat dari Melaka pula dengan adanya alat seperti tunggul dua belas, payung, bekasnya seroja, gong, gendang dan serunai.

\title{
MEMBENTUK SIFAT KEPATUHAN RAKYAT
}

Pada zaman kesultanan Melayu, kepatuhan rakyat menjadi asas penting dalam hubungan di antara raja dan rakyat dalam sesebuah tampuk pemerintahan. Dalam konteks hubungan tersebut, kuasa memainkan peranan penting dalam usaha melahirkan sifat kepatuhan rakyat terhadap raja. Menurut Norhayati Abd. Rahman (2009:3), konsep kuasa atau kekuasaan diistilahkan sebagai keupayaan seseorang itu untuk membuat peraturan dan memastikan pematuhan terhadapnya (the power or right to give orders and make others obey). Berdasarkan kenyataan tersebut, kuasa mampu melahirkan kepatuhan rakyat kepada golongan pemerintah. Jika dilihat dalam sejarah raja-raja Melayu, kekuasaan raja dapat diwujudkan melalui konsep daulat. Norhayati Abd. Rahman menjelaskan lagi konsep daulat dapat dikaitkan dengan konsep 'kena tulah'. Dengan wujudnya konsep-konsep tersebut, rakyat harus mematuhi segala titah dan arahan daripada raja. Hal ini kerana, masyarakat Melayu percaya rakyat yang ingkar akan dianggap derhaka. Menurut Siti Hawa Haji Salleh (2006:16) rakyat yang patuh dan taat menerima ganjarannya sementara yang menentang akan menerima padahnya.

Dalam kajian ini, sifat kepatuhan rakyat difokuskan kepada undang-undang jenayah. Hal ini demikian kerana dalam naskhah undang-undang Kedah terdapat beberapa undang-undang jenayah yang telah diwujudkan oleh golongan raja kepada rakyat dalam usaha baginda untuk mengukuhkan 
kekuasaannya. Antaranya, melalui undang-undang yang berkaitan hukum membunuh dan mencuri. Dalam naskhah Undang-Undang Kedah, setiap hukum yang diwujudkan akan dikenakan hukuman. Contohnya, hukum orang membunuh telah dijelaskan dengan terperinci dalam naskhah UndangUndang Kedah. Ini dapat dilihat dalam petikan di bawah:

\begin{abstract}
"Fasal pada menyatakan hukum orang membunuh tiada dengan setahu raja-raja atau tiada orang besar itu, jikalau dibunuhnya dengan dosanya sekalipun, hukumnya denda sepuluh tahil sepaha, salahnya tiada memberitahu raja atau hakim (sekalipun) harus dibunuh, tiada salahnya. Adapun jikalau ada ia tertangkap atau dipertegahkan maka dosanya patut dibunuh, maka dibunuhnya".
\end{abstract}

(Undang-Undang Kedah, 2005:51)

Berdasarkan petikan di atas, hukuman yang dikenakan kepada mereka yang membunuh ialah denda sebanyak sepuluh tahil dan hukuman berat iaitu bunuh. Naskhah Undang-Undang Kedah juga turut menyatakan hukuman yang dikenakan bagi orang yang membunuh madunya. Ini dijelaskan dalam petikan di bawah:

"Adapun jikalau membunuh madunya itu, lari ia ke dalam kampung orang, maka diikutnya oleh empunya madu itu masuk kampung itu, maka berkelahi orang empunya kampung itu, maka jikalau melawan maka dibunuh yang mengikut itu, mati sahaja, tiada kata hukum lagi”.

(Undang-Undang Kedah, 2005:51)

Selain itu, naskhah ini juga telah memperihalkan undang-undang membunuh terhadap hamba yang hendak membunuh tuannya. Ini diperlihatkan melalui petikan di bawah:

\begin{abstract}
"Adapun jika hamba itu hendak membunuh tuannya, maka orang lain menangkap dia, harus dibunuh, jikalau jauh tempat, lagi tiada kuasa menangkap. Adapun jika dekat, maka ditangkapnya, lalu dibunuhnya, maka kenalah dendanya lima tahil sepaha kerana taksir tiada tahu tuannya dan tiada tahu menteri itu. Maka jika luka payah maka lalu dibunuhnya oleh tuannya itu, tiada salah lagi dibunuhnya. Itulah hukum abdi..”.
\end{abstract}

(Undang-Undang Kedah, 2005:52)

Hukuman juga dikenakan kepada individu atau golongan tertentu seperti golongan merdeheka yang membunuh hamba orang akan dikenakan denda dan hukuman bunuh. Ini diperlihatkan dalam petikan di bawah:

"Fasal yang ketujuh pada menyatakan hukum merdeheka membunuh hamba orang. Adapun jika hamba raja dibunuh maka akan dendanya tujuh kali tujuh. Jikalau ia lepas, dibunuh".

(Undang-Undang Kedah, 2005:53)

Manakala, hukuman juga dikenakan kepada orang besar-besar jika mereka membunuh hamba raja. Ini diperlihatkan seperti petikan di bawah:

“Adapun jika membunuh hamba raja akan orang besar-besar dendanya sekati lima dan jikalau dibunuh itu dengan salahnya, tiada lagi perkataannya itu”.

(Undang-Undang Kedah, 2005:53) 
Berdasarkan penghuraian di atas, hukuman yang dikenakan merupakan atas perintah atau arahan daripada golongan raja. Hukuman tersebut menjadi salah satu kaedah yang digunakan oleh golongan raja dalam memperkukuhkan kuasa mereka di samping mampu melahirkan kepatuhan rakyat kepada raja. Seterusnya, undang-undang yang membicarakan hal yang berkaitan mencuri dijelaskan melalui beberapa fasal. Antaranya, ialah berkaitan hukuman yang dikenakan kepada individu yang mencuri di dalam kampung, mencuri di dalam rumah, mencuri tanam-tanaman, mencuri perahu dan hukuman yang dikenakan kepada individu yang mencuri binatang ternakan. Namun dalam perbincangan ini, analisis hanya akan melihat kepada hukuman yang dikenakan kepada individu yang mencuri di dalam kampung dan di dalam rumah sahaja. Hukum bagi orang yang mencuri di dalam kampung dapat dilihat dalam petikan di bawah:

\begin{abstract}
"Fasal yang kesebelas pada menyatakan hukum orang mencuri lagi dalam kampung, maka tahu orang empunya kampung itu, maka dibunuhnya atau diturutinya jauh antara dua kampung maka dibunuhnya, tiadalah salah lagi pada yang membunuh itu. Adapun jikalau kemudian hari daripada itu maka bertemu ia dengan orang mencuri itu tiadalah dapat dibunuh melainkan hukum juga datang kepadanya".
\end{abstract}

(Undang-Undang Kedah, 2005:55)

Orang yang mencuri akan dikenakan hukuman yang berat iaitu bunuh. Di sini jelas memperlihatkan raja pada zaman kesultanan Kedah mengambil isu ini sebagai satu perkara yang serius. Jika diteliti hukuman yang dikenakan akan mewujudkan rasa takut rakyat kepada raja. Ini menyebabkan rakyat akan menuruti perintah tersebut walaupun dilihat tidak adil bagi mereka. Manakala, bagi orang yang mencuri di dalam rumah pula akan dikenakan hukum puntung dan dikenakan hukuman takzir (hukuman dengan cara diberi malu). Ini dijelaskan dalam petikan di bawah:

"Adapun jika ia mencuri di dalam/rumah itu nescaya datanglah hukum puntung padanya. Adapun jika banyak pergi mencuri itu maka naik ke rumah itu seorang, yang lain tiada naik, maka seorang itu juga dipuntung, yang banyak kata takzir. Adapun erti takzir itu, iaitu naik kerbau putih, dibubuh sunting dengan bunga raya, berpayung tudung saji, maka conteng mukanya dengan arang dan kunyit, dibawa berkeliling negeri, dipinta hak yang mencurinya itu. Jika sudah habis dimakannya,maka tuannya memberi ganti. Adapun jikalau ia merdeheka, masuk ulur ia pada yang empunya harta".

(Undang-Undang Kedah, 2005:55)

Hukuman yang dikenakan bagi orang yang mencuri di dalam rumah berbeza dengan hukuman orang yang mencuri di dalam kampung. Di sini jelas memperlihatkan bahawa hukuman yang dijatuhkan melihat kepada sebesar mana tahap kesalahan yang dilakukan. Rumusannya, setiap kesalahan akan dikenakan hukuman. Melalui hukuman tersebutlah sebenarnya raja memperkukuhkan kuasa mereka. Di sini memperlihatkan rakyat harus taat dengan segala perintah raja. Ini kerana menurut Muhammad Mustaqim Mohd Zarif (2016:16), menjadi kewajiban rakyat untuk mentaati segala perintah dan dasar yang diperkenalkan oleh perintah mereka. Oleh itu, mahu tidak mahu rakyat harus mentaati pemerintahnya.

\title{
KESIMPULAN
}

Secara keseluruhannya, semasa pemerintahan zaman kesultanan Melayu Kedah raja merupakan tunggak penting dalam mengetuai sesebuah masyarakat. Dalam mengetuai sesebuah pemerintahan ketaatan dan kepatuhan rakyat menjadi titik tolak kepada jatuh bangun kedudukan seseorang raja itu. Oleh yang demikian, aspek yang paling penting dalam pemerintahan diraja ialah "kuasa". Disebabkan oleh kuasa, golongan raja telah menjalankan pelbagai kaedah bagi mengekal dan memperkukuhkan kekuasaan mereka itu. Berdasarkan analisis perbincangan kaedah yang digunakan 
iaitu mewujudkan pembatasan hubungan raja dengan rakyat, melalui kawalan sosial dan membentuk sifat kepatuhan rakyat bukan sahaja mampu mengekalkan kekuasaan raja, namun menyerlahkan kebijaksanaan golongan raja dalam mengetuai rakyatnya. Di samping itu, kaedah yang dijalankan ini juga mampu membentuk keamanan dan keharmonian negara terutamanya melalui penggubalan undang-undang.

\section{RUJUKAN}

A.Samad Ahmad. (1996). Sulalatus Salatin (Sejarah Melayu). Kuala Lumpur: Dewan Bahasa dan Pustaka. French, J.R.P.Jr. \& Raven, B. “The Bases of Social Power”, in D. Cartwright (Ed), Studies in Social Power. Ann Arbor. Univ. Of Michigan Press. 1959: 150-167.

Harun Mat Piah, Ismail Hamid et al. (2000). Kesusasteraan Melayu Tradisional. Kuala Lumpur: Dewan Bahasa dan Pustaka..

Jelani Harun. Kajian naskhah undang-undang adat Melayu di London. SARI: Jurnal Alam dan Tamadun Melayu, 26. 2008:127-148.

Jelani Harun. Pemerintahan dan politik dalam naskhah Melayu. Seminar Wacana Kesultanan Melayu: Pemerintahan dan Politik. 2016: 1-42.

Jelani Harun. (2008). Undang-Undang Kesultanan Melayu dalam Perbandingan. Pulau Pinang: Penerbit USM.

Mariyam Salim. (2000). Undang-Undang Kedah. Kuala Lumpur. Dewan Bahasa dan Pustaka.

Muhammad Mustaqim Mohd Zarif. Raja sebagai wakil tuhan dalam sastera Kitab Melayu. Seminar Wacana Kesultanan Melayu: Pemerintahan dan Politik. 2016:1-21.

Norhayati Ab. Rahman. Adat dan adat istiadat dalam sastera sejarah sebagai peneguhan kepada ketuanan dan kekuasaan Raja Melayu. Seminar Kebangsaan Kekuasaan dalam Sastera Melayu Nusantara. 2009.

Noriah Taslim. (2008). "Sulalat-us-Salatin dan strategi ketahanan politik Melayu abad ke-17" dalam Sulalatus-Salatin (Sejarah Melayu): Cerakinan Sejarah, Budaya dan Bahasa. Pulau Pinang : Penerbit Universiti Sains Malaysia.

R.J. Wilkinson. (1970). Malay Laws, in Reading in Malay Adat Law. Singapore. University of Singapore Press.

Siti Hawa Haji Salleh. (2006). Naskhah Melayu Berunsur Sejarah (Kerajaan Melayu) dalam Siri Kajian Naskhah Kesultanan Melayu. Kuala Lumpur: Dewan Bahasa dan Pustaka.

Yusuf Iskandar. Sejarah Melayu dan Adat Istiadat. Dewan Bahasa. Oktober 1977:663.

Zainal Abidin Borhan. Lambang kedaulatan kesultanan Melayu: Padi berbuahkan emas, berdaunkan perak, berbatangkan suasa. Seminar Wacana Kesultanan Melayu: Pemerintahan dan Politik. 2016: 1-16.

Zubir Idris. Kuasa dan hubungan timbal-balik dalam Syair Perang Mengkasar. Seminar Kebangsaan Kekuasaan dalam Sastera Melayu Nusantara. 2009. 